\title{
The 'Hau' of Research: Mauss Meets Kaupapa Māori
}

\section{GEORGINA STEWART}

Te Kura Mātauranga School of Education, AUT University, Aotearoa-New Zealand (g.stewart@aut.ac.nz)

'The Gift' is the English title of a small book. first published in French in 1925 by sociologist Marcel Mauss, which catalyzed an ongoing debate linked to a wide range of scholarship. Mauss's gift theory included the Mãori example of the 'bau of the gift' which Mauss explained as a spiritual force, seeking to return to its original owner or place of origin. This article brings a critical Mäori perspective to Mauss' notion of the hau of the gift, in an indigenous philosophical response to Eurocentric social science that combines critical discourse analysis (CDA) with Kaupapa Mäori theory and principles of research. The paper introduces Mauss' arguments about gifting, and the role of hau in those arguments, before turning to a close examination of the concept of 'bau' as presented in the original Mäori letters, the primary data used by Elsdon Best to write his anthropological articles, from which Mauss developed his ideas about hau. These letters, which sparked the whole debate, are material artefacts of the crosscultural educational relationship between Tamati Ranapiri as teacher, and Elsdon Best as student. Common-sense Mãori readings of Ranapiri find no mystery in what he wrote about hau, but reinforce the significance of his correspondence, from the perspective of Kaupapa Mäori versions of the history of Mäori education.

Key Words: Gift theory; Hau of the gift; Indigenous knowledge; Intercultural hyphen; Kaupapa Māori; Marcel Mauss; Tamati Ranapiri

\section{Introduction}

This article uses the principles of Kaupapa Māori research methodology ${ }^{1}$ to present a Māori reading of the debate that began in 1925 with Essai sur le don [The Gift], a small book ${ }^{2}$ by French sociologist Marcel Mauss that has "generated more debate, discussion, and ideas than any other work of anthropology" (Graeber 2001: 152). ${ }^{3}$ Mauss asked why gifts must be repaid in "backward or archaic" societies: "What power resides in the object given that causes its recipient to pay it back?" (Mauss 1990: 4) Early in the first chapter, Mauss introduces the Māori concept of the "hau' of the gift, which he describes as a "spiritual power" (ibid: 15) seeking to return to its original owner or place of origin. Due to the importance of Mauss' book, his notion of the 'hau of the gift' has also become wellknown within the social sciences. From today's perspective it is axiomatic that language and cultural phenomena can only be fully interpreted from within the paradigm or worldview of that cultural identity, but throughout many decades of debate about all aspects of Mauss's ideas, including his use of hau, Māori voices have been noticeably silent. The 'hau of the gift' is a clear example of Eurocentric appropriation of indigenous knowledge: a concept extracted by social science from its authentic cultural contex $\mathrm{t}^{4}$ and re-inscribed within the Western discourses of the modern academy.

'He iti pioke, he marangai' is a traditional saying from the people (iwi) of the far north of Aotearoa: it refers to a large ocean wave caused by a small shark. This proverb is fitting for the ripples of influence that have spread outwards from the debate about the 'hau of the gift.' Today there is even an open-access journal of anthropological theory that bears its name, Hau Journal (www.haujournal.org). This article offers a Māori response: it is an attempt to 'do' indigenous philosophy: a 'rescue operation' of some kind. To undertake this research is to heed the ghostly call of the reo tuppuna (ancestral tongue) from the tantalizing archive of intercultural encounter between colonial science and Māori ancestors.

Journal of World Philosophies 2 (Summer 2017): 1-11

Copyright (C) 2017 Georgina Stewart.

e-ISSN: 2474-1795 • http://scholarworks.iu.edu/iupjournals/index.php/jwp• doi: 10.2979/jourworlphil.2.1.01 
The analytical approach used in this research is a Kaupapa Māori version of critical discourse analysis (CDA), following the delineation of CDA by Terry Locke as:

a scholarly orientation with the potential to transform the modus operandi of a range of research methodologies. In respect of educational research, it has the potential to reveal the way power is diffused through the prevalence of various discourses throughout an education system. ${ }^{5}$

This form of $\mathrm{CDA}$ focuses on the central ideas and messages found in the textual corpus, which are reinforced and modified by various characteristics of the text, both linguistic and extra-linguistic. ${ }^{6}$ Fortuitously, Locke's description of CDA aligns with the principles of Kaupapa Māori research, delineated by Graham Smith as:

- $\quad$ related to 'being Māori';

- connected to Māori philosophy and principles;

- $\quad$ taking for granted the legitimacy and importance of Māori language and culture; and

- $\quad$ concerned with the struggle for autonomy over our own cultural well being. ${ }^{7}$

Thus, Kaupapa Māori research methodology is defined in terms of its political stance, rather than in technical terms such as methods for data collection and analysis. The political orientation of Kaupapa Māori research seeks to redress the historical oppression of Māori people, knowledge and culture, inherent in mainstream social science research philosophies and practices: it is a response by Māori to dominant detrimental stories told by Pākehā (White settler, mostly of British origin) research about Māori (Smith 2003).

The 'hau of the gift' is a topic that is suitable to tackle using Kaupapa Māori philosophy. ${ }^{8}$ This article takes a Māori-centred viewpoint to re-examine Mauss's original interpretations of Māori ideas, and the ensuing commentary. The alignment between CDA and Kaupapa Māori warrants their use in combination in this work. Both CDA and Kaupapa Māori attend to the theoretical and philosophical underpinnings of research, which direct what questions are asked, and why: questions more fundamental than those concerning methods used for data collection and analysis. In accordance with Kaupapa Māori principles, Māori text is normalized in this article: nonitalicized; and using the standard orthography at the time of writing, 2016, with macrons for long vowels.

Due to the age of Mauss's text, it is necessary to 'read past' its overt sexism: in relation to gifts and exchange, it takes for granted that women can be traded or given away, thus lumping women together with chattels, animals etc. It is also necessary to read past the underpinning racism that formed part and parcel of the modernist paradigm then-current in science, within which Mauss wrote. Modernist science blinded itself to its own limits 9 such as those imposed by fallacious racist and sexist beliefs. This blindness results in scientism, or distorted versions of science, ${ }^{10}$ in particular the ideology of evolutionism, a key item of scientism against which Kaupapa Māori provides one useful form of resistance. ${ }^{11}$ The influence of evolutionism, for example, underpins the placement of societies along a unitary timeline, leading to modern or Western culture at its apotheosis, which was part of the accepted framework of scientific theory of Mauss' time. ${ }^{12}$ The next section introduces Mauss' book and its arguments, commenting on the role of 'hau' in those arguments, and the reasons why his book became so important in sociology, anthropology and beyond.

\section{He iti pioke: The Gift by Marcel Mauss}

Mauss was among the early generations of sociologists, seen as the "intellectual successor to his uncle, Emile Durkheim, the founder of French sociology." (Graeber 2001: 152). In The Gift Mauss set out to critique the principles of Western economic theory and the "rise of the market as the main medium of human relations" (ibid). Mauss surveyed a wide range of indigenous cultures through the literature, gathering together examples of how gifting and other forms of exchange operate in non-Western societies. Mauss was also an active socialist, and 
through his scholarship he sought to contribute to the development of a socialist theory and philosophy for an alternative vision of the future of (Western) society (ibid: 155-8).

As already noted, Mauss's book has generated a steady parade of scholarly works through the decades, with famous responses including those of Raymond Firth, ${ }^{13}$ Claude Levi-Strauss, ${ }^{14}$ Marshall Sahlins, ${ }^{15}$ Marcus Gregory, ${ }^{16}$ Annette Weiner, ${ }^{17}$ and Maurice Godelier, ${ }^{18}$ to name only a few. Today, it continues to inspire new generations of scholars across a range of fields including psychology, ${ }^{19}$ philosophy, ${ }^{20}$ and others. ${ }^{21}$ It would be superfluous to attempt any kind of rehearsal: instead, this section leans mainly on a chapter by David Graeber, ${ }^{22}$ which provides a particularly erudite, readable and comprehensive review of Mauss's work in context, and the ensuing debate, written from a 21 st-century point of view, starting with his declaration, "I believe Mauss' theoretical corpus is the single most important in the history of anthropology" (ibid: 151).

Graeber insightfully relates Mauss' work to that of Karl Marx as the leading socialist theorist, saying that it

complements Marx because it represents the other side of socialism. Marx's work consists of a brilliant and sustained critique of capitalism; [but] he carefully avoided speculating about what a more just society would be like. Mauss' instincts were quite the opposite: he was much less interested in understanding the dynamics of capitalism than in trying to understand—and create—something that might stand outside it (ibid: 161).

In his book Mauss undertook an "exploration of the notion of the social contract" (ibid: 152) arguing that in what Mauss referred to throughout as 'our own societies,' meaning 'the West,' the ideas of gifting and economic exchange have come to be falsely regarded as separate and opposing in nature, in what amounts to a reified binary at the heart of Western economic discourse, which has of course continued to become more and more dominant since Mauss wrote. ${ }^{23}$ The term 'reified binary' is applicable because, just as the "pure self-interest" (Graeber 2001: 155) of market theory is an unconvincing caricature of human nature, so also gifts understood as "acts of pure disinterested generosity, are logically impossible" (ibid: 161). Thus "the whole idea of a free gift is based on a misunderstanding." ${ }^{4}$ Rather, Mauss was interested in the "entanglement" between the two ideas: "the gift-like qualities of commodities and the commodity-like properties of gifts." 25

Mauss was not trying to describe how the logic of the marketplace, with its strict distinctions between persons and things, interest and altruism, freedom and obligation, had become the common sense of modern societies. Above all, he was trying to explain the degree to which it had failed to do so (Graeber 2001: 162).

Its inherently paradoxical nature explains why the concept of the gift has become "the hidden face of modernity"(ibid: 161) because one can always find reasons for saying that gifts "are not really gifts at all" (ibid). Graeber argues that this paradox has been built into (Western) social theory, which

[speaks] of social ties without using the words that are associated with them in daily life: surrender, forgiveness, renunciation, love, respect, dignity, redemption, salvation, redress, compassion, everything that is at the heart of relationships between people (ibid).

Graeber concludes that the many forms of gifting and exchange- those surveyed by Mauss, and those found in contemporary Western society-fall more logically into two categories he calls "open" and "closed" reciprocity: open-handed hospitality, including what Mauss termed "total prestation" on the one hand; and careful accounting, according to the nuances of the relationship between the actors involved, on the other.

Open reciprocity keeps no accounts, because it implies a relation of permanent mutual commitment; it becomes closed reciprocity when a balancing of accounts closes the relationship off, or at least maintains the constant possibility of doing so (ibid: 220).

Journal of World Philosophies 2 (Summer 2017): 1-11 
This binary thus turns on an axis of temporality: whether a transaction tends towards gift or commodity depends on whether the relationship between donor and recipient is considered to be permanent or delimited. The binary in Western thinking

between freedom and obligation is, like that between interest and generosity, largely an illusion thrown up by the market, whose anonymity makes it possible to ignore the fact that we rely on other people for just about everything (ibid: 221).

Whereas the taonga (valuables) and other gift objects Mauss discussed in his book carry 'traces' of their former owners and histories, money by contrast is generic and resistant to history (ibid: 213-4). In short, it is the 'inhuman' nature of the market that allows us to believe we can satisfy our needs and wants without ethical consideration of the needs and wants of those with whom we engage in so doing. It also seems reasonable to suggest that this disconnection via the market from the 'others' with whom we engage in carrying on our economic activities is responsible for acceptance of the otherwise implausible 'unlimited greed' as defining the default position of market actors, or 'homo economicus.'

Mary Douglas called The Gift a "grand exercise in positivist research" (1990: xi) since it rested on Mauss' assumptions, firstly, that general rules about human behaviour and society exist; that these rules can be derived by scientific research; and that such research would provide humanity with "moral conclusions" by which to guide its future direction (Mauss 1990: 107). Since Mauss was one of the early generations of sociologists, he was in a sense inventing sociology as he undertook his research. He used the archives of anthropology as if they were a source of 'primary data' that he could mine to investigate his questions. His way of doing sociology was therefore rather like what might today be called a 'critical literature review' —or even a type of CDA, as described in the Introduction section, above. The apparent insignificance of the subject of 'the gift' belies the centrality of the ideas with which Mauss engaged: the entanglement of people and relationships with possessions; ideas of reciprocity and generosity; the workings of families, friendships, and organizations; and above all, seeking to articulate a vision of a better future for society.

In making his arguments, Mauss took the Māori concept of 'hau taonga' as an example to place in contrast against the Western idea of a 'free gift.' 'Hau taonga' was part-translated as the 'hau of the gift,' also expressed as the "spirit of the thing given" (ibid: 13), or the "spirit of the gift" (Sahlins 1972). Mauss interpreted the 'hau of the gift' as suggesting that in Māori traditions, a gift object has some kind of supernatural power, which actively seeks to return to its original owner or place of origin. This 'hau of the gift' idea furnished a dramatic answer to Mauss' central question about the 'power' of the object given. Its dramatic nature is possibly why Marshall Sahlins called this idea Mauss' "master concept" (ibid: 149) in the sense of a simple, hence 'pure' illustration of the obligation to reciprocate, involved in giving and receiving gifts. The next section turns to a more detailed examination of this intriguing Māori concept.

\section{He marangai: A Māori Reading of the 'Hau of the Gift'}

In his exploration of Māori concepts, Mauss relied on papers written by Elsdon Best, who was one of the foremost cultural anthropologists to study Māori prior to 1900. Best consulted by letter with "Tamati Ranapiri, of Ngāti Raukawa, a man who possessed much curious knowledge pertaining to Native forest lore," 26 in his quest to understand and record traditional Māori knowledge, then undergoing rapid change as a result of colonization. Tamati Ranapiri is the acknowledged original author of this famous paragraph, but little else about him has been published (private records probably exist, and further biographical research may well be warranted, but lies beyond the scope of this article). ${ }^{27}$ Ranapiri has been widely referred to as a 'Māori sage' (Sahlins 1972: 150) or expert. 'Tamati' is a transliteration of Thomas, and 'Ranapiri' is a transliteration of Ransfield, suggesting he may have been one of the early generations of rangatira (leaders) to adopt an English name, usually on Christian baptism, and to learn to read and write in Māori, which was the approach taken in the early years of missionary education. Six years 
before the letter he wrote to Best, discussed in the next section, Ranapiri published a paper ${ }^{28}$ on traditional methods of bird and rat snaring, co-authored with S. Percy Smith, who was a contemporary of Best. This interesting paper consists of Ranapiri's essay in te reo Māori, followed by a complete translation into English by Smith. In these collaborations — cited by Best, and co-authored with Smith—Ranapiri's written words became verbatim scientific data in the archives of anthropology, which have been debated and theorized about ever since by many non-Māori scholars.

\section{Ranapiri Extracts in Māori and Translated into English}

Two key Ranapiri paragraphs as reported by Best in his 1909 paper are reproduced below, the first followed by Bruce Biggs' translation, ${ }^{29}$ and the second by Best's own translation. In Best's paper, these two Māori paragraphs appear in sequence, exactly as shown below, but Best omitted to translate the connecting sentence (Whāngainga o te hau ngāherehere) into English, a gap I have accordingly filled. ${ }^{30}$

Paragraph 1:

Nā, mō te hau o te ngāherehere. Taua mea te hau, ehara i te mea ko te hau e pupuhi nei. Kāore. Māku e āta whakamārama ki a koe. Nā, he taonga tōu ka hōmai e koe mōku. Kāore a tāua whakaritenga utu mō tō taonga. Nā, ka hōatu hoki e ahau mō tētehi atu tangata, à ka roa pea te wā, ā ka mahara taua tangata kei a ia rā taua taonga kia hōmai he utu ki a au, à ka hōmai e ia. Nā, ko taua taonga i hōmai nei ki a au, ko te hau tēnā o te taonga i hōmai rā ki a au i mua. Ko taua taonga me hōatu e ahau ki a koe. E kore rawa e tika kia kaiponutia e ahau mōku; ahakoa taonga pai rawa, taonga kino rānei, me tae rawa taua taonga i a au ki a koe. Nōtemea he hau nō te taonga tēnā taonga na. Ki te mea ka kaiponutia e ahau taua taonga mōku, ka mate ahau. Koinā taua mea te hau, hau taonga, hau ngāherehere. Kāti ēnā (Best 1909: 441).

\section{Paragraph 1 translated by Biggs:}

Now, concerning the hau of the forest. This hau is not the hau that blows (the wind). No. I will explain it carefully to you. Now, you have something valuable which you give to me. We have no agreement about payment. Now, I give it to someone else, and, a long time passes, and that man thinks he has the valuable, he should give some repayment to me, and so he does so. Now, that valuable which was given to me, that is the hau of the valuable which was given to me before. I must give it to you. It would not be correct for me to keep it for myself, whether it be something very good, or bad, that valuable must be given to you from me. Because that valuable is a hau of the other valuable. If I should hang onto that valuable for myself, I will become mate [sick or dead]. So that is the hau—hau of valuables, hau of the forest. So much for that (Sahlins 1972: 152).

\section{Paragraph 2:}

Whāngainga o te hau ngāherehere. Ka whakamārama ahau ki a koe mō te hau ngāherehere. Ko te mauri, nā te tohunga i hōatu (whakanoho) ki te ngāherehere. Nā te mauri te manu i whakahua ki te ngāherehere, ka tîkina atu e te tangata, ka patua, ka riro mai i te tangata. Ko ēnei manu he taonga nō te mauri rāua ko te tohunga, me te ngāherehere, arā he utu mai nō te taonga o te ngāherehere, arā o te mauri. Koia i kīa ai kia whāngaia te hau o te ngāherehere. Mā ngā tohunga e kai, nā rātou hoki te mauri. Koia i wehea ai ètehi o ngā manu i tunua ai ki te ahi tapu mā ngā tohunga anake e kai, koia tērā, kia hoki te hau o te taonga o te ngāherehere me te mauri ki te ngāherehere anō, arā ki te mauri. Kāti ēnā (Best 1909: 441).

\section{Paragraph 2 translated by Best:}

[Nurturing the hau of the forest.] I will explain something to you about the forest hau. The mauri ${ }^{31}$ was placed or implanted in the forest by the tohunga [priests]. It is the mauri that causes birds to be abundant in the forest, that they may be slain and taken by man. These birds are the property of, or belong to, the mauri, the tohunga, and the forest: that is to say, they are an equivalent for that important item, the mauri. 
Hence it is said that offerings should be made to the hau of the forest. The tohunga (priests, adepts) eat the offering because the mauri is theirs: it was they who located it in the forest, who caused it to be. That is why some of the birds cooked at the sacred fire are set apart to be eaten by the priests only, in order that the hau of the forest-products, and the mauri, may return again to the forest - that is, to the mauri. Enough of these matters (ibid: 439).

The affordances of the internet allow for one more step, in seeking to re-animate the words of Tamati Ranapiri and his efforts to teach Best about Māori concepts. An image of just the first page of an actual letter written by Ranapiri to Best can be viewed online. ${ }^{32}$ Below is my own rendering in English of this page, as read from this online image, preserving line breaks and formatting, and completing the sentence at the end of the handwritten page, which ends mid-sentence with the word 'whāngai' meaning 'nurture,' by referring to the 1909 Best paper (1909: 440).

Manakau (a place near Otaki)

7 October 1901

To Best (Peehi), Greetings, my friend

I have here your letter of the 13th of last month, received by me, with your questions. Well, my friend, I may not be able to answer some of your questions, but those which I feel equipped to answer, let me do so. Question 1. The mauri of the forest, and the hau of the forest. My friend, I've already spoken about the mauri of the forest in my previous explanations about killing and catching birds. In short, the mauri is a karakia that was performed by the tohunga using some object such as a stone or stick, or some other object favoured by the tohunga as a resting place and holder of the mauri. [The mauri] was deposited into one of those objects, and it was left to lie in a hidden place in the forest.

Concerning the hau of the forest

There are two aspects of the hau of the forest

1 is the view of the forest as seen by those who inspect it to see if there are sufficient birds to make it worthwhile for them to hunt that day. The first bird they kill is given for the mauri, flung into the forest while declaring it to be for the mauri, in order that their subsequent efforts might not be unsuccessful.

2 when the hunt is finished, the fowlers exit the forest and begin to cook the birds by the huahua process (in which the birds are placed in vessels and boiled using heated stones), setting some aside to nurture [the hau of the forest: that is the 'hau ngāherehere'].

While not adding substantively to previously-published discussions of Best's data, the peripheral text included above offers glimpses of Ranapiri the letter-writer: a person, located in space and time, in an embodied relationship with his material and his correspondent, his friend 'Peehi.' The next section presents original commentary on hau, as explained to Best by Ranapiri.

\section{Reading Ranapiri on hau taonga, hau ngäherehere}

In relation to the notion of the 'hau of the gift' - translated as the 'spirit of the gift' - I would agree with the general consensus that Mauss read more into this concept than warranted, and in so doing created a caricature or cartoon form $^{33}$ of the indigenous Māori concept of 'hau taonga.' Nor is much enlightenment to be found in the subsequent studies that have attempted to improve on Mauss' interpretation - a corpus boasting complicated diagrams and convoluted explanations. Even Graeber's insightful reading of hau as a means by which to forestall tapu (2001: 183) is unconvincing, given that Ranapiri made no necessary link between tapu (sacred) and hau in his 'careful explanation.'

It is not that hau and tapu are unrelated: in Māori thinking, humans constantly negotiate a balance, or utu, between the cosmic poles, including that of tapu and noa (secular). Spiritual forces are ubiquitous but unseen, like the air. The everyday meaning of 'hau' is wind: we only sense air when it moves. Likewise, the esoteric meaning of 
hau is the detectable movement of spiritual force, carried by the acts, intentions and associated objects, of those with whom we interact. Hence, the thing someone gives us, in return for a valuable we were given in the first place, carries the spiritual force or memory of those relationships, and is referred to metaphorically as the hau taonga. Analogously, in the ceremony of 'whāngainga o te hau ngāherehere,' (nurturing the hau of the forest), some of the birds caught in the forest are set aside to be cooked and eaten, under strictest tapu conditions, by the tōhunga (priests) only, as 'representatives' of Tane. This ceremony is a way of restoring the hau ora (health) of Tane, in repayment for the gifts of his children, the birds.

As a Māori-speaking researcher, it makes sense to consider other usages of this meaning of 'hau' in te reo Māori (the Māori language). One pertinent example is 'hau kāinga' (kāinga means 'home'), a term for those people who 'keep the home fires burning.' From the traditional language of the far northern iwi, this phrase conveys the same sense of a vital essence as in 'hau taonga' and 'hau ngāherehere' and is also a two-word phrase with 'hau' followed by a modifying word. Another example is 'haututu,' commonly used in relation to a misbehaving child. ${ }^{34}$ The word 'tutu' is a verb that means 'to play around' and 'haututu' is another 'hau' phrase, used to refer to a spirit of mischief, of the same form as 'hau taonga' and 'hau ngāherehere.' The final example is the well-known Māori word for health, 'hauora.' Broken into the two component words, 'hau ora' is another 'case' of hau, with ora signifying wellness and safety. This phrase showcases hau as a carrier or mediator between the cosmic poles (including that of ora-mate [life-death]) from which the Māori cosmos is constructed. ${ }^{35}$

Other commentators have noted that Mauss' interpretation of 'hau taonga' slipped from the idea of an 'essence' or 'force' to something more individualized and animate, approaching what might be termed a 'ghost.' It is easy to see how this slippage is encouraged by these two meanings of the one English word 'spirit,' but in te reo Māori these two ideas, 'essence' and 'ghost,' are conveyed by quite separate words and could never become confused. Similar problems of translation arise with 'the hau of the gift' and 'the hau of the forest.' At least part of the problem seems to arise from the English phrase 'of the, ${ }^{36}$ which conveys a truncated sense of the meaning, or more precisely, range of meanings, conveyed in Māori by two-word phrases that combine a noun such as hau, followed by various modifying words, as in the five 'hau' phrases under consideration: hau taonga, hau ngāherehere, hau kāinga, hau tutu, hau ora.

To translate 'hau taonga' and 'hau ngāherehere' as 'hau in relation to valuables' and 'hau in relation to the forest' gives slightly different nuances of meaning for these two key phrases, which perhaps better convey their Māori meanings. A similar point can be made for the phrase 'tangata whenua' and its common but inadequate rendition in English as 'people of the land. ${ }^{37}$ Relatedly, Tanemahuta (Tane) is commonly glossed as the 'god of the forest,' but this phrase also falls short of the full range of Māori meanings, since Māori concepts straddle multiple dimensions simultaneously. ${ }^{38}$ Whilst Tane is god 'of' the forest, the forest is also literally part 'of' Tane, and the birds and other living things of the forest are his children. When Tane is in good spirits (hau ora) birds are plentiful in the forest.

Ranapiri wrote to Best in answer to his queries concerning his studies of Māori forest lore and the 'art of the fowler' so it must have been 'hau ngāherehere' that Best asked him to explain. In his letter, Ranapiri tells Best he is going to carefully explain the hau of the forest, then immediately turns to his explanation of hau in relation to gifts and valuables, in what has become "quite possibly the most quoted paragraph in all of anthropology." 39 This passage led Mauss to speculate about the 'hau of the gift' thereby initiating all the subsequent decades of debate. But in Ranapiri's mind, 'hau' as social obligation was clearly the familiar, taken-for-granted idea, which he used as an analogy for the more esoteric notion of hau as obligation to the forest, in other words to Tane, of the Māori fowler when hunting birds. Hence the need for the ceremony of 'whāngai hau' to nurture the hau of the forest, by repaying Tane for his gifts to humans.

The Western scientific edifice that examines Māori knowledge has long been familiar with the Māori genealogical model of the cosmos, in which all the living and non-living elements of the world were understood as kin, common descendants of the primordial parent gods Ranginui ('father sky') and Papatūānuku ('earth mother'), and their children the departmental gods, namely Tane and his brothers Tangaroa (god of oceans), Tāwhirimātea (god of winds) and others. ${ }^{40}$ Nevertheless, there seems to have been a general failure to follow through on the implications of this model, in relation to this and other ethnographic analyses of Māori concepts.

Journal of World Philosophies 2 (Summer 2017): 1-11

Copyright (C) 2017 Georgina Stewart.

e-ISSN: 2474-1795 • http://scholarworks.iu.edu/iupjournals/index.php/jwp• doi: 10.2979/jourworlphil.2.1.01 
Best certainly seemed to understate the link between 'hau ngāherehere' and Tane: "The offering of birds made to the hau of the forest was probably originally an act of placation or conciliation of the gods of the forest_-of Tane and others" (1909: 440).

Relying on Best's analysis, Mauss followed suit, omitting any mention of Māori customs from his section on "the present made to humans, and the present made to the gods" (1990: 18) that followed just a few pages after his section on 'hau.' Western scholars ever since have attempted to explain Māori concepts, but without taking account of the kinship relationships between humans, gods and non-human aspects of the natural world, which form their underpinning 'theoretical framework' or Māori paradigm of knowledge. The cosmogenic narratives were dismissed as myths and legends, and excised from discussions of Māori knowledge of the natural world. ${ }^{41}$

Mauss failed to account for the personified Māori cosmos, and ended up invalidly personifying 'hau' instead, in his delineation of 'hau taonga' as the 'hau of the gift'- the 'spirit' of the object given. In this way, Mauss distorted the Māori concept of hau to serve his preconceived search for universal social truth, and a general theory of exchange. To reconcile Māori concepts such as hau within larger Māori understandings of the world, portrayed through the cosmogenic narratives, is part and parcel of the paradigm and purpose of Kaupapa Māori theory and principles of research. ${ }^{42}$ This analysis, undertaken from my perspective as a Māori educational researcher, leaves little mystery attached to what Ranapiri wrote about hau, but restores to his writings their due significance, as notable literary inventions emerging from his cross-cultural educational relationship with Best: working the hyphen between Māori and Pākehā worlds. ${ }^{43}$

\section{Conclusion: the Hau of Research}

In the last few pages of his book, Mauss turned to comment on schooling and its role in realizing any vision for the future of humanity, noting "the mutual respect and reciprocating generosity that is taught by education" (1990: 106). This statement contrasts with economistic aims of schooling, under the marketized policies of the last 30odd years. Mauss saw education as key to "the civics" (ibid: 107), prefiguring what would later become Social Studies in the school curriculum. Mauss was using ethnographic data to form a mirror, held up in order to allow modern society to see its own reflection; an attempt to gain a critical perspective on his own culture, the European. Hau is an interesting example of an indigenous concept appropriated, not into general language, ${ }^{44}$ but into certain restricted language domains. Graeber's statement about the Ranapiri paragraph being possibly the most quoted in all of anthropology supports the claim made by Linda Smith that Māori are one of the most researched of all indigenous peoples. ${ }^{45}$ The archives of anthropology, such as Best's 1909 paper, have been formative in the development of the social sciences and the disciplines of the academy as a whole. To reflect on the interplay between the archive, the academy and society at large is to appreciate anew the 'power' of the written word. Kaupapa Māori philosophy is a strategic deployment of that power: a discursive act that speaks back to the archive, re-positioning Mauss within a Māori history of scholarship about Māori knowledge; mining Eurocentric science for indigenous purposes, under the umbrella of the wider intellectual project of Kaupapa Māori. ${ }^{46}$

Spanning oceans and literacies in Māori, English and French for well over a century, many scholars and thinkers have held a great conversation about the gift, which has included extensive debate about the notion of the 'hau of the gift.' As a Māori academic in education, I first heard this phrase recently in London for a World Philosophies workshop on my first visit to the UK. Intrigued, I began to investigate, eventually resulting in this article. The gift of writing thus invokes a 'hau' of research, in that the research archive enables but does not determine any particular question that might be asked, such as that which motivates this research.

These epistolary relationships of Tamati Ranapiri with Best and Smith form a remarkable example of the intercultural hyphen between Māori and Pākehā worlds, worthy of further exploration, beyond this current focus on hau. Ranapiri as a Māori scholar was operating in innovative, productive ways facilitated by early Māori literacy and bi-lateral educational relationships ${ }^{47}$ Ranapiri was inventing Māori academic writing as he wrote: writing about and in language that hitherto had existed only in oral registers. Other than Ranapiri, only one other scholar of Māori ethnicity, namely Biggs, appears in the history of debate about the hau of the gift.

Journal of World Philosophies 2 (Summer 2017): 1-11

Copyright (C) 2017 Georgina Stewart.

e-ISSN: 2474-1795 • http://scholarworks.iu.edu/iupjournals/index.php/jwp• doi: 10.2979/jourworlphil.2.1.01 
Best presented the Ranapiri extracts and their translations out of sequence, and with incoherent explanations. Mauss distorted what Best wrote about 'hau taonga' to suit his socialist purposes. Sahlins offered thanks to Biggs, but not co-authorship. The intersections between the developing disciplines and the larger sociopolitical history of the times are captured in the textual archives that inform philosophical research in education, where this research is located. Flaws and all, the rich research archive on the hau of the gift rewards the diligence and nurtures the creativity of advanced literacy in such forms of secondary research as this. By such means, among others, research offers its gifts to humanity, and to the future.

Georgina Stewart (ko Whakarārā te maunga, ko Matauri te maona, ko Ngāti Kura te hapū, ko Ngāpuhi-nuitonu te iwi) is a senior lecturer in Te Kura Mātauranga School of Education, AUT University, Auckland, Aotearoa-New Zealand. She has a background teaching science, mathematics and te reo Māori (Māori language) in high schools, and in her doctoral work investigated the Māori science curriculum. Her research explores various aspects of the philosophical nexus between language, knowledge, culture and education.

Graham Hingangaroa Smith, "Kaupapa Māori Theory: Theorizing Indigenous Transformation of Education and Schooling." Paper presented at Joint AARE/NZARE Conference, Auckland, 2003. (retrieved from: aare.edu.au/data/publications/2003/pih03342.pdf, last accessed on 20 January 2017).

Marcel Mauss, The Gift: The Form and Reason for Exchange in Archaic Societies, trans. Wilfred D. Halls (New York: Norton, 1990).

David Graeber, Toward an Anthropological Theory of Value: The False Coin of Our Own Dreams (New York: Palgrave Macmillan, 2001).

David Thompson, "The Hau of the Gift in Its Cultural Context," Pacific Studies 11, no. 1, (1987): 63-79. Terry Locke, Critical Discourse Analysis (London and New York: Continuum, 2004).

Norman Fairclough, and Isabela Fairclough, Political Discourse Analysis (Abingdon, UK \& New York: Routledge, 2012).

L.T. Smith, Decolonizing Methodologies: Research \& Indigenous Peoples, 2nd edition (London, and Dunedin: Zed Books, 2012), 187.

Georgina Stewart, "Indigenous Philosophies and Education: The Case of Kaupapa Māori," EEPAT Encyclopaedia of Educational Philosophy and Theory, 2016 (DOI: 10.1007/978-981-287-532-7_177-1). Carl Te Hira Mika, "Overcoming 'Being' in Favour of Knowledge: The Fixing Effect of 'Mātauranga,' " Educational Pbilosophy and Theory 44, no. 10, (2012): 1080-92 (DOI:10.1111/j.1469-5812.2011.00771.x). Tom Sorell, Scientism: Philosophy and the Infatuation with Science (London and New York: Routledge, 1991). Georgina Stewart, Good Science? The Growing Gap between Power \& Education (Rotterdam: Sense, 2010). Robert L. Carneiro, Evolutionism in Cultural Anthropology: A Critical History (Boulder, CO: Westview Press, 2003).

13 Raymond Firth, Economics of the New Zealand Mãori, 2nd edition (Wellington: Government Printer, 1972).

14 Claude Levi-Strauss, Introduction to the Work of Marcel Mauss, trans. Felicity Baker (London: Routlege \& Kegan Paul, 1987).

15 Marshall D. Sahlins, "The Spirit of the Gift," in Stone Age Economics (New York: Aldine \& De Gruyter, 1972), 149-83.

16 Christopher Gregory, Gifts and Commodities (Studies in Political Economy) (London: Academic Press, 1982).

17 Annette Weiner, Inalienable Possessions: The Paradox of Keeping-While-Giving (Berkeley: University of California Press, 1992).

18 Maurice Godelier, The Enigma of the Gift (Cambridge UK: Polity Press, 1999).

19 Robert A. Emmons, and Michael E. McCullough, The Psychology of Gratitude (Oxford, New York: Oxford University Press, 2004). 2011); ed. Alan D. Schrift, The Logic of the Gift: Towards an Ethic of Generosity (New York: Routledge, 1997). 
21

ed. Aafke E. Komter, The Gift: An Interdisciplinary Perspective (Amsterdam: Amsterdam University Press, 1996); Rauna Kuokkanen, Reshaping the University: Responsibility, Indigenous Epistemes, and the Logic of the Gift (Vancouver: UBC Press, 2007).

David Graeber, Toward an Anthropological Theory of Value: The False Coin of Our Own Dreams (Palgrave Macmillan, 2001).

Nesta Devine, Education and Public Choice: A Critical Account of the Invisible Hand in Education (Westport CT: Praeger, 2004); David Graeber, Debt - the First 5,000 Years (New York: Melville House, 2011).

Mary Douglas, "No Free Gifts," Foreword to the Gift by M. Mauss (New York: Norton, 1990), ix.

Amiria Henare, Museums, Anthropology and Imperial Exchange (Cambridge UK: Cambridge University Press, 2005), 114.

Elsdon Best, "Māori Forest Lore: Being Some Account of Native Forest Lore and Woodcraft, as Also of Many Myths, Rites, Customs, and Superstitions Connected with the Flora and Fauna of the Tuhoe or Urewera District - Part 3," Transactions and Proceedings of the Royal Society of New Zealand 1868-1961, vol. 42, 1909, 433-81 (http://rsnz.natlib.govt.nz/volume/rsnz_42/rsnz_42_00_004640.html, p. 438).

National archives hold original records of Ranapiri from 1872-1907, including these letters and records from the Māori Land Court, but note that his birth and death dates are unknown.

Tamati Ranapiri and S. Percy Smith, "Nga Ritenga Hopu Manu a Te Māori, O Mua. Ancient Methods of Bird-Snaring Amongst the Maoris," The Journal of the Polynesian Society 4, no. 2, (1895): 132-52.

The need for a new translation is discussed in Sahlins (1972: 151).

See sentence in square brackets at the start of Paragraph 2 translation, below.

Mauri means 'vital essence' and refers to both the spiritual quality itself, and to the talisman used to house it. Ranapiri also equates mauri with the karakia or priestly rites by which it was managed — see discussion of his letter in the following paragraphs.

Retrieved from: http://mp.natlib.govt.nz/detail/?id=69684\&t=items\&q=Māori\&f $=$ collection $\$$ Heritage $\% 20$ Images $\& u=0 \& \mathrm{~s}=\mathrm{a} \& \mathrm{l}=\mathrm{en} \& \mathrm{tc}=0 \& \mathrm{recordNum}=0 \&$ numResults $=200 \& \mathrm{p}=0$ (last accessed on 25 April 2017).

Christopher Jocks, "Living Words and Cartoon Translation: Longhouse "Texts" and the Limitations of English," Endangered Languages: Current Issues and Future Prospects, ed. Lenore A. Grenoble and Lindsay J. Whaley (Cambridge University Press, 1998); Elizabeth McKinley, "Māori in Science and Mathematics Education," Te Ara Pütaiao: Mãori Insights in Science, ed. J. S. Te Rito and S. M. Healy, Ngā Pae o te Māramatanga, 2008, 27-36 (http://www.maramatanga.ac.nz/sites/default/files/TO\%20Te\%20Ara $\% 20 \mathrm{P} \% \mathrm{C} 5 \%$ ABtaiao $\% 20$ Maori $\% 20$ scientists.pdf).

Used either as an adjective meaning something like 'mischievous' or as an imperative exclamation directed to the child: "Haututu!" meaning "Leave that alone!"

See Anne Salmond, "Te Ao Tawhito: A Semantic Approach to the Traditional Māori Cosmos," Journal of the Polynesian Society 87, no. 1, (1978): 5-28.

A link seems likely between this translational inadequacy and "the two senses of 'of"- - a distinction attributed to philosopher John Searle, see ed. Sofia Miguens, and Gerhard Preyer, Consciousness and Subjectivity (Heusenstamm: Ontos Verlag, 2012).

The common translation is inadequate because 'tangata whenua' more accurately means 'traditional owners.'

Carl Mika, "Māori Thinking with a Dead White Male," Knowledge Cultures 2, no. 1, (2014): 22-39.

Graeber (2001). Shown as Paragraph 1 in the previous sub-section.

See, for example, "Children of Heaven and Earth," in Sir George Grey, Polynesian Mythology (Christchurch: Whitcombe and Tombs, 1956), 1-11.

For an example of this approach see Firth (1972).

Examples of this approach include: Anne Salmond, "Ontological Quarrels: Indigeneity, Exclusion and Citizenship in a Relational World," Anthropological Theory 12, no. 2, (2012): 115-41; "Te Ao Tawhito: A Semantic Approach to the Traditional Māori Cosmos," Journal of the Polynesian Society 87 (1978): 5-28. 
43 Alison Jones, and K. Jenkins, "Rethinking Collaboration: Working the Indigene-Colonizer Hyphen," Handbook of Critical and Indigenous Methodologies, ed. N. K. Denzin et al. (Los Angeles: Sage, 2008), 471-86; Georgina Stewart, "From Both Sides of the Indigenous-Settler Hyphen in Aotearoa New Zealand," Educational Philosophy and Theory, 2016 (DOI: 10.1080/00131857.2016.1204904).

44 Like many other Māori borrowings in New Zealand English, see Joan Metge, Tuamaka: The Challenge of Difference in Aotearoa New Zealand (Auckland: Auckland University Press, 2010).

45 L. T. Smith, Decolonizing Methodologies: Research \& Indigenous Peoples, 2nd edition (London: Zed Books, 2012).

46 Te Kawehau Hoskins, "A Fine Risk: Ethics in Kaupapa Māori Politics," New Zealand Journal of Education Studies: Te Hautaka Mãtai Mãtauranga 47, no. 2, (2012): 85-99.

47 Alison Jones, and K. Jenkins, He Körero-Words between Us: First Māori-Päkehā Conversations on Paper (Wellington: Huia, 2011). 